\title{
Investigation into modelling of a fuel cell stack system.
}

ALI, D.M. and SALMAN, S.K.

2006

(C) 2006 IEEE. Personal use of this material is permitted. Permission from IEEE must be obtained for all other uses, in any current or future media, including reprinting/republishing this material for advertising or promotional purposes, creating new collective works, for resale or redistribution to servers or lists, or reuse of any copyrighted component of this work in other works. 


\title{
INVESTIGATION INTO MODELLING OF A FUEL CELL STACK SYSTEM
}

\author{
D. Morsi Ali and S.K. Salman
}

Robert Gordon University, UK

\begin{abstract}
Noticing the rise in the electricity prices, worrying about the $\mathrm{CO}_{2}$ emissions and global warming and not sure about living with nuclear Power stations, makes everyone think from where energy will come in the coming years. What is needed is a zero-emission distribution generation technology or combination of technologies that allows clean, cost effective supply of energy, on demand on a large scale and in any location. In response a momentous energy revolution is taking place, renewable energy generation or decentralized power systems like wind, photovoltaic, as well as new hydrogen and fuel cells technologies are developing nowadays to take over from fossil hydrocarbons combustion.

This paper proposes a model for the simulation and performance evaluation of a Polymer Electrolyte Membrane (PEM) fuel cell generation system. Although other models [1-6] have been produced, the proposed model strength is modularizing the fundamental thermal-physical behaviour of a fuel cell stack to develop a modular block that can be used as a part of any other schematic solution required for fuel cells' study. The developed modular block (prototype) makes the model easy to modify to allow the simulation of any PEMFC with different cell parameters and allows investigation of its behaviour for any operating or design configuration. It is also useful for the study of integration of fuel cells in distribution power systems (which is promising especially to systems with variable output renewable sources as it can store their excess power thus improving the overall system stability). The proposed model exhibits most of the basic fuel cell properties and incorporates essential physical and electrochemical processes that happen along its operation, thus it can be moderated to model any other fuel cell' type.

The proposed model prototype was verified and compared to another simplified model [2] by generating sample results for a Ballard V Proton Exchange Membrane Fuel Cell (PEMFC) stack. Results indicate that the developed prototype is more accurate in simulating the fuel cell stack and predicting its performance especially for high operating current densities.
\end{abstract}

KEYWORDS: Renewable Energy, Clean Environment, Fuel cells, Mathematical modelling, Block Simulation

\section{INTRODUCTION}

Most of the world's $115 \mathrm{GW}$ p.a. power consumption is still generated from the combustion of fossil fuels. This technology, despite of its advanced development, is inefficient (max. efficiency about 50\%), lead to a global warming (generate almost $35 \%$ of greenhouse emissions), as well as becoming expensive and insecure (recent instability of the oil prices). Fuel cells are electrochemical devices that convert the chemical energy of a gaseous fuel directly into electricity, heat and water thereby eliminating pollution. They combine the best features of engines (can operate for as long as fuel is available) and batteries (produce electricity directly from fuel without combustion reducing emissions and noise and increasing efficiency). Two of their major benefits are their ability to provide power and heat at different scales and in locations not currently accessible; and their ability to operate on fuels ranging from fossil fuels through biomass based fuels to renewable. PEMFCs have more advantages like their high power densities, solid electrolyte-long cell \& stack life, low corrosion and higher efficiency which made them attractive for almost all applications and the centre of interest for excessive research. Thus this paper will present a modular block (prototype) to simulate the PEMFCs. The proposed thermodynamic model prototype was verified by generating sample results for a Ballard V PEMFC stack, taken from Laurencelle et al (2001), in which each cell has an active area of $50.6 \mathrm{~cm}^{2}$ and works at low temperature of $70^{\circ} \mathrm{C}$. Results from the verification investigation indicate that the developed prototype is accurate in simulating a PEM fuel cell stack and predicting its performance. Generated results were then compared to those generated from another prototype developed using a simplified model [2]; comparison showed that the proposed model is more accurate in simulating the fuel cell, especially at operating current densities higher than $1 \mathrm{~A} / \mathrm{cm}^{2}\left(1000 \mathrm{~mA} / \mathrm{cm}^{2}\right)$.

\section{THE FUEL CELL SYSTEM}

A fuel cell stack is formed of a number of cells referred as MEA (Membrane-electrode assembly) composed of a membrane (electrolyte) sandwiched between two porous electrodes. The stack' voltage is determined by the number of cells, and current is determined by the active area of the cells. Other parts of a fuel cell system include pumps and blowers, compressors, cooling system, a power conditioning (voltage regulator to make the cell DC output suitable for connection to an electrical load) and sometimes a DC/AC inverter. A fuel processing system will be needed if the fuel cell does not use pure hydrogen. A controller is needed to coordinate the parts of the system. In case of PEMFC, there is often a need to humidify one or both of the reactant gases. The fuel cell system consists in general of four sections as in Fig. 1.

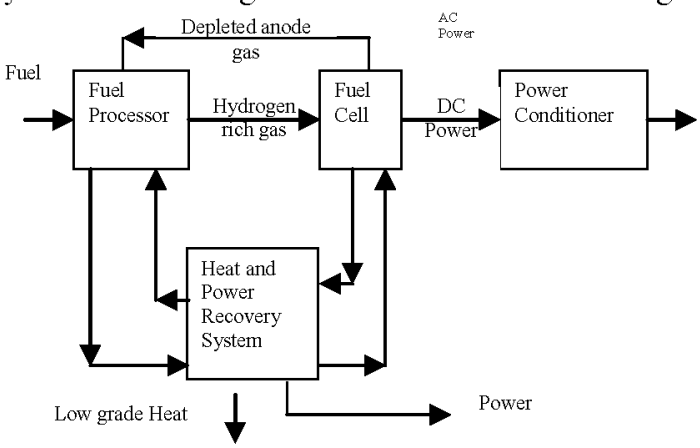

Fig. 1 Block Diagram of a Fuel cell Power Plant 


\section{PEMFC BASIC PRINCIPLES AND MODELLING}

A PEMFC depends primarily on a modified polymer membrane (Nafion: as it is mechanically strong, can absorb large quantities of water and is good proton conductor), coated with highly dispersed catalyst particles (best is platinum although it is the major factor in the cost of PEMFC). The electrodes are usually flat and porous so that both the electrolyte from one side and the gas from the other side can penetrate it. The operating temperature for PEMFC is between 50 and $90^{\circ} \mathrm{C}$.

The electrochemical equations are given by:

At Anode: $\quad \mathrm{H}_{2} \rightarrow 2 \mathrm{H}^{+}+2 \mathrm{e}$

At Cathode: $2 \mathrm{H}^{+}+2 \mathrm{e}^{-}+1 / 2 \mathrm{O}_{2} \rightarrow \mathrm{H}_{2} \mathrm{O}+$ heat

Overall reaction: $\mathrm{H}_{2}+1 / 2 \mathrm{O}_{2} \rightarrow \mathrm{H}_{2} \mathrm{O}+$ heat

Where the first equation determines the amount of hydrogen needed to meet a load, second equation determines amount of oxygen needed to maintain reaction, while third equation determines water produced. The energy released is given by the change in the Gibbs free energy of formation $\Delta \mathbf{G}_{\mathbf{f}}$, which is the difference between the Gibbs free energy of products and that of inputs or reactants. It is more convenient to consider these quantities in their per mole form $\left(\mathrm{g}_{\mathrm{f}}\right)$.

$\therefore \Delta g_{f}=g_{f}$ of products $-g_{f}$ of reactants

$\therefore \Delta \mathrm{g}_{\mathrm{f}}=\left(\mathrm{g}_{\mathrm{f}}\right)_{\mathrm{H} 2 \mathrm{O}}-\left(\mathrm{g}_{\mathrm{f}}\right)_{\mathrm{H} 2}-1 / 2\left(\mathrm{~g}_{\mathrm{f}}\right)_{\mathrm{O} 2}$

Gibbs free energy of formation is not constant; it changes with temperature and state (liquid or gas) as in table 1.

Table $1 \Delta \mathbf{g}_{\mathrm{f}}$ for the reaction $\left(\mathrm{H}_{2}+1 / 2 \mathbf{O}_{2} \rightarrow \mathbf{H}_{2} \mathbf{O}\right)$ at various temperatures:

\begin{tabular}{|l|l|l|}
\hline $\begin{array}{l}\text { Form of water } \\
\text { product }\end{array}$ & $\begin{array}{l}\text { Temperature } \\
\left({ }^{\circ} \mathrm{C}\right)\end{array}$ & $\begin{array}{l}\Delta \mathrm{g}_{\mathrm{f}} \\
\left(\mathrm{kJmol}^{-1}\right)\end{array}$ \\
\hline Liquid & 25 & -237.2 \\
Liquid & 80 & -228.2 \\
Gas & 80 & -226.1 \\
Gas & 100 & -225.2 \\
Gas & 200 & -220.4 \\
Gas & 400 & -210.3 \\
Gas & 600 & -199.6 \\
Gas & 800 & -188.6 \\
Gas & 1000 & -177.4 \\
\hline
\end{tabular}

Note that -ve sign means that energy is released. In the following sections steps of modelling a PEMFC are given:

\subsection{Anode and Cathode (Reactants) flow Models:}

In these models the dynamically varying pressure of the reactant gas flows (hydrogen and air) are calculated.

To calculate the $\mathrm{O}_{2}$ usage rate:

We know from the basic reaction of fuel cell that 4 electrons are transferred for each mole of oxygen,

$\therefore$ Charge $=4 \mathrm{~F} \mathrm{X}$ amount of oxygen

$\therefore$ Oxygen usage $($ rate $)=\mathrm{I} / 4 \mathrm{~F}$ moles $/ \mathrm{s}$

Where: F: Faraday constant or the charge on one mole of electrons $=96.485 \mathrm{C}$

For a stack of $(\mathrm{N})$ cells:

Oxygen usage $=\mathrm{IN} / 4 \mathrm{~F}$ moles $/ \mathrm{s}$

Or, since $\mathrm{P}=\mathrm{V}_{\mathrm{FC}} \times \mathrm{I} \times \mathrm{N}$, then $\mathrm{I}=\mathrm{P} / \mathrm{NV}_{\mathrm{FC}}$, where $\mathrm{P}$ is the fuel cell power, $\mathrm{V}_{\mathrm{FC}}$ is voltage of each cell.

$\therefore$ Oxygen usage $=\mathrm{P} / 4 \mathrm{~F} \mathrm{~V}_{\mathrm{FC}}$ moles $/ \mathrm{s}$

From the molar mass of $\mathrm{O}_{2}$

$\therefore$ Oxygen usage $=8.29 * 10^{-8} *\left(\mathrm{P} / \mathrm{V}_{\mathrm{FC}}\right) \mathrm{Kg} / \mathrm{s}$

However the molar proportion of oxygen in air is 0.21 ;

$\therefore$ Air usage $=3.57 * 10^{-7} *\left(\mathrm{P} / \mathrm{V}_{\mathrm{FC}}\right) \mathrm{Kg} / \mathrm{s}$
To calculate the $\mathrm{H}_{2}$ usage rate:

Similarly, from the basic reaction of fuel cell 2 electrons are transferred for each mole of hydrogen, so:

Charge $=2 \mathrm{~F}^{*}$ amount of hydrogen

$\therefore$ Hydrogen usage $=\mathrm{I} / 2 \mathrm{~F}$ moles $/ \mathrm{s}$

Or, Hydrogen usage $=\mathrm{P} / 2 \mathrm{~F} \mathrm{~V}_{\mathrm{FC}}$ moles $/ \mathrm{s}$

The molar mass of $\mathrm{H}_{2}$ is $2.02 * 10^{-3} \mathrm{~kg} / \mathrm{mol}$

$\therefore$ Hydrogen usage $=1.05 * 10^{-8} *\left(\mathrm{P} / \mathrm{V}_{\mathrm{FC}}\right) \mathrm{Kg} / \mathrm{s}$

The $\mathrm{H}_{2}$ usage rate is useful to know the electrical energy that could be produced from a given mass or volume of hydrogen [Specific enthalpy $(\mathrm{HHV})=39.7 \mathrm{kWh} / \mathrm{kg}$ ].

\subsection{Membrane Hydration Model:}

This represents the process of water transfer across the membrane. Dry membranes reduce proton conductivity and flooded ones block the pores in the electrodes leading to high voltage losses. Ideally, air (oxygen) blown over the cathode diffuse water from the cathode to the anode and throughout electrolyte and dry out any excess water providing a suitable state of hydration, but perturbations can happen. Thus an adjustable parameter $\psi[7$ and 8], that is influenced by membrane preparation procedure and relative humidity; will be included in the proposed model.

$\psi=14$ under ideal condition of $100 \%$ relative humidity.

$\psi=22$ or 23 under oversaturated conditions.

\subsection{Stack Voltage Model:}

The typical electrical characteristic of a fuel cell is normally given in the form of a polarization curve, which is a plot of the cell voltage versus cell current density (current/unit cell active area). The difference between actual voltage $V_{\text {F.C }} \&$ ideal voltage of a fuel cell $E_{\text {Nernst }}$ represents the losses in the cell. As more current is drawn the voltage decreases (due to the $\mathrm{FC}$ electrical resistance, inefficient reactant gas transport $\&$ slow reaction). As low voltage indicates low efficiency of the $\mathrm{FC}$, then low load operation is preferred. Notice that since Gibbs free energy of formation changes with temperature $\&$ state, thus the polarization curve varies with different operating conditions as different temperatures, reactant partial pressures and membrane humidity. Therefore, the voltage model should calculate the stack voltage as a function of stack current, reactant partial pressures, cell temperature, and membrane humidity using a combination of physical and empirical relationships. The $\mathrm{o} / \mathrm{p}$ voltage for a PEMFC is basically defined by $[7,8]$ :

$\mathrm{V}_{\mathrm{F} . \mathrm{C}}=\mathrm{N}\left[\mathrm{E}_{\mathrm{Nernst}}-\mathrm{L}\right]$

Where:

$\mathrm{V}_{\mathrm{F} . \mathrm{C}}=$ Stack o/p voltage.

$\mathrm{N}=$ Number of cells forming the stack.

$\mathrm{E}_{\text {Nernst }}=$ Cell potential obtained in an open-circuit thermodynamic balance (no load).

$\mathrm{L}=$ Voltage losses $=\Delta \mathrm{V}_{\text {activation }}+\Delta \mathrm{V}_{\text {ohmic }}+\Delta \mathrm{V}_{\text {conc }}$

\section{- To find $\mathbf{E}_{\text {Nernst }}$ :}

As it was shown before for each mole of hydrogen 2 electrons flow, thus the flowing charge is:

Charge $=-2 \mathrm{~F}$ coulombs

Electrical work done $=$ charge $\times$ voltage

$\therefore \Delta \mathrm{g}_{\mathrm{f}}=-2 \mathrm{FE}$ joules

$\therefore \mathrm{E}=-\Delta \mathrm{g}_{\mathrm{f}} / 2 \mathrm{~F}$

Where: $\mathrm{E}$ is the maximum electromotive force or 
reversible produced open circuit voltage of fuel cell at standard temperature $25^{\circ} \mathrm{C}$.

$\Delta \mathrm{g}$ f: change in Gibbs free energy $(\mathrm{J} / \mathrm{mol})$, which is the available energy to do external work.

To obtain $E_{N e r n s t}$ an extra term is added to take into account changes in temperature with respect to standard reference temperature $25^{\circ} \mathrm{C}$.

$\therefore \mathrm{E}_{\mathrm{Nernst}}=-\Delta \mathrm{g}_{\mathrm{f}} / 2 \mathrm{~F}+\Delta \mathrm{S} / 2 \mathrm{~F}\left(\mathrm{~T}-\mathrm{T}_{\mathrm{ref}}\right)$

Where: $\triangle \mathrm{S}$ : Change of the entropy $(\mathrm{J} / \mathrm{mol})$

$$
\Delta \mathrm{g}_{\mathrm{f}}=\left(\mathrm{g}_{\mathrm{f}}\right)_{\mathrm{H} 2 \mathrm{O}}-\left(\mathrm{g}_{\mathrm{f}}\right)_{\mathrm{H} 2}-1 / 2\left(\mathrm{~g}_{\mathrm{f}}\right)_{\mathrm{O} 2}
$$

As the Gibbs free energy changes with reactant pressure and concentration; Thus

$$
\begin{aligned}
& \Delta \mathrm{g}_{\mathrm{f}}=\Delta \mathrm{g}_{\mathrm{fo}}+\mathrm{RT} \ln \left[\frac{\mathrm{P}_{\mathrm{H}_{2} \cdot\left(\mathrm{P}_{\mathrm{O} 2}\right)^{1 / 2}}}{\mathrm{P}_{\mathrm{H} 2 \mathrm{O}}}\right] \\
& \therefore \mathrm{E}=\mathrm{E}_{\mathrm{O}}+\mathrm{RT} \ln \left[\frac{\left.\mathrm{P}_{\mathrm{H} 2} \cdot\left(\mathrm{P}_{\mathrm{O} 2}\right)^{1 / 2}\right]}{\mathrm{P}_{\mathrm{H} 2 \mathrm{O}}}\right.
\end{aligned}
$$

Where: $E_{\mathrm{o}}$ is the cell EMF at standard pressure

$\mathrm{R}$ : Universal gas constant $=8.3145 \mathrm{~J} / \mathrm{kg} . \mathrm{K}$

$\mathrm{T}$ : Fuel cell temperature in $\mathrm{K}$

$\mathrm{P}_{\mathrm{H} 2}, \mathrm{P}_{\mathrm{O} 2}, \mathrm{P}_{\mathrm{H} 2 \mathrm{O}}$ : Partial pressures of hydrogen, oxygen and water.

From equations (3), (4) and by substituting with the known values of the constants and the reference temperature, we obtain the final equation:

$\mathrm{E}_{\mathrm{Nernst}}=1.229-0.85 * 10^{-3 *}(\mathrm{~T}-298.15)+4.3085 * 10^{-}$ $5 * \mathrm{~T} *\left[\ln \left(\mathrm{P}_{\mathrm{H} 2}\right)+1 / 2 \ln \left(\mathrm{P}_{\mathrm{O} 2}\right)\right]$

\section{- To find the losses $L$ :}

This is divided to activation losses, crossover losses, ohmic losses and concentration losses [7].

\section{Activation losses}

This is due to slowness of reactions taking place in the cell. A proportion of the generated voltage is lost in driving the chemical reaction that transfers electrons to or from the electrode.

$$
\begin{aligned}
& \therefore \Delta V_{\text {act }}=A \ln (\mathrm{i} / \mathrm{b}) \\
& \mathrm{A}=\mathrm{A}_{\mathrm{a}}+\mathrm{A}_{\mathrm{c}} ; \text { and } \mathrm{b}=\mathrm{i}_{\mathrm{oa}}(\mathrm{Aa} / \mathrm{A})+\mathrm{i}_{\mathrm{oc}}(\mathrm{Ac} / \mathrm{A})
\end{aligned}
$$

Where $\mathbf{A}$ (Tafel slope) is a constant in volts and $\mathbf{b}$ is a constant in amperes. $\mathbf{A}$ is higher for a slow reaction, and $\mathbf{i}_{\mathbf{0}}$ is higher for a fast reaction, a higher $\mathbf{i}_{\mathbf{o}}$ will reduce the activation losses and improve the fuel cell performance.

\section{Fuel crossover and internal currents}

This energy loss results from the waste of fuel passing through the electrolyte (fuel crossover), as well as some electron conduction through the electrolyte (electrolyte should only transport ions), resulting in a noticeable voltage drop (added to the activation losses). Thus the final Cell activation losses become:

\begin{tabular}{|l|}
\hline$\Delta \mathrm{V}_{\text {act }}=\mathrm{A} \ln \left[\left(\mathrm{i}+\mathrm{i}_{\mathrm{n}}\right) / \mathrm{i}_{\mathrm{o}}\right]$ \\
Where: $\mathrm{i}_{\mathrm{n}}$ is the internal and fuel crossover equivalent
\end{tabular} current density.

\section{Ohmic losses or resistive losses:}

This is due to either internal current losses caused by the leakage of some electrons passing through the membrane instead of being utilized, or due to resistive losses caused by electrons flow through the resistance of the whole electric circuit (hydrated membrane reduces ohmic losses). It is proportional to current density.

$$
\Delta \mathrm{V}_{\mathrm{ohm}}=\mathrm{ir}
$$
(8)

Where $r$ : is the area-specific resistance.

\section{Mass transport or Concentration losses:}

This is due to the change in concentration of reactants at the surface of the electrodes as the fuel is used causing reduction in the partial pressure of reactants, resulting in a reduction in voltage given by:

$\Delta \mathrm{V}_{\text {trans }}=-\mathrm{RT} / \mathrm{n}^{\prime} \mathrm{F} \cdot \ln \left(1-\mathrm{i} / \mathrm{i}_{1}\right)$

Where: $n$ ' differs for different reactants (it is 2 for hydrogen and 4 for Oxygen).

Or by another approach [8] that is entirely empirical and has become more favoured lately, because it gives same results, provided constants $m$ and $n$ are chosen properly:

$\Delta \mathrm{V}_{\text {trans }}=-\mathrm{m} \exp (\mathrm{ni})$

The value of $\mathrm{m}$ will typically be about $3 \times 10^{-5} \mathrm{~V}$, and $\mathrm{n}$ about $8 \times 10^{-3} \mathrm{~cm}^{2} / \mathrm{mA}$.

Combining all losses, the cell voltage becomes:

$\mathrm{V}=\mathrm{E}-\Delta \mathrm{V}_{\text {ohm }}-\Delta \mathrm{V}_{\text {act }}-\Delta \mathrm{V}_{\text {trans }}$

$\therefore \mathrm{V}=\mathrm{E}-\mathrm{i} \cdot \mathrm{r}-\mathrm{A} \cdot \ln \left[\left(\mathrm{i}+\mathrm{i}_{\mathrm{n}}\right) / \mathrm{i}_{\mathrm{o}}\right]+\mathrm{m} \cdot \exp (\mathrm{ni})$

Where: $\mathrm{E}$ : is the reversible open circuit voltage (OCV) given by equation (2).

Equation (11) is often simplified in a practical way as the crossover current $i_{n}$ is usually very small.

$\therefore \mathrm{V}=\mathrm{E}-\mathrm{ir}-\mathrm{A} \ln \left(\mathrm{i} / \mathrm{i}_{\mathrm{o}}\right)+\mathrm{m} \exp (\mathrm{ni})$

$\mathrm{V}=\mathrm{E}-\mathrm{ir}-\left(\mathrm{A} \ln (\mathrm{i})-\mathrm{A} \ln \left(\mathrm{i}_{\mathrm{o}}\right)\right)+\mathrm{m} \exp (\mathrm{ni})$

Put constants together, so: $E_{o c}=E+A \ln \left(i_{0}\right)$

$\therefore \mathrm{V}=\mathrm{E}_{\mathrm{oc}}-\mathrm{ir}-\mathrm{Aln}(\mathrm{i})+\operatorname{mexp}(\mathrm{ni})$

This simplified emperical model [2] was checked here after developing a SIMULINK modular block for it [9]. Example values of the used constants are given by table 2 . Results obtained, figures $2 \& 3$, shows that this model is only accurate in simulating the fuel cell at operating current densities up to $1 \mathrm{~A} / \mathrm{cm}^{2}$.

Table (2) Example constants for equation 14:

\begin{tabular}{|l|l|}
\hline Constant & Ballard Mark V PEMFC at $70^{\circ} \mathrm{C}$ \\
\hline $\mathrm{E}_{o c}(\mathrm{~V})$ & 1.031 \\
$\mathrm{r}\left(\mathrm{k} \Omega \mathrm{cm}^{2}\right)$ & $2.45 \times 10^{-4}$ \\
$\mathrm{~A}(\mathrm{~V})$ & 0.03 \\
$\mathrm{~m}(\mathrm{~V})$ & $2.11 \times 10^{-5}$ \\
$\mathrm{n}\left(\mathrm{cm}^{2} / \mathrm{mA}\right)$ & $8 \times 10^{-3}$ \\
\hline
\end{tabular}

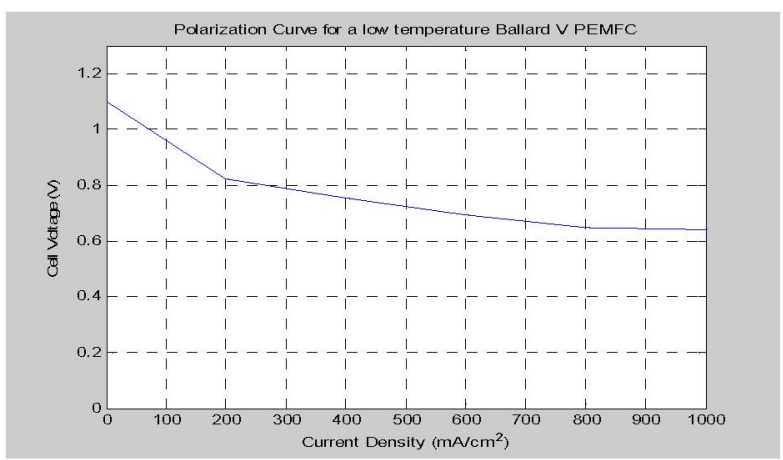

Fig. 2: Resulting Polarization Curve on using the simplified empirical model (The operating current density only up to 1000 $\mathrm{mA} / \mathrm{cm}^{2}$ or $1 \mathrm{~A} / \mathrm{cm}^{2}$ )

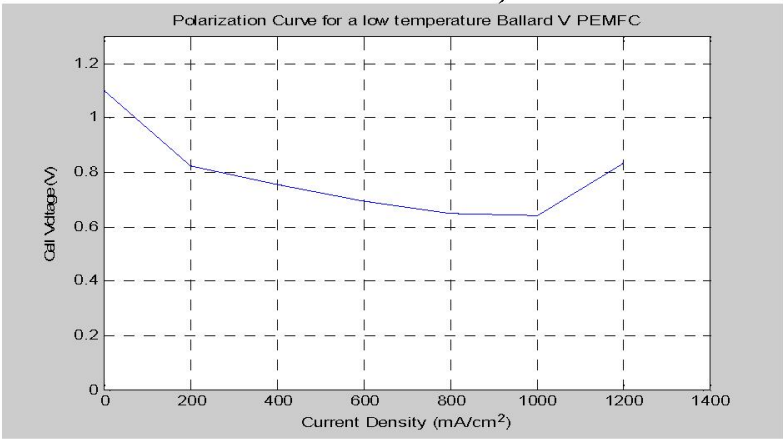

Fig. 3: Resulting Polarization Curve on using simplified empirical model (But the operating current density exceeds 1000 $\mathrm{mA} / \mathbf{c m}^{2}$ or $1 \mathrm{~A} / \mathrm{cm}^{2}$ 


\subsection{Proposed Model:}

A more exact (non-simplified) model is proposed here, in which equation (5) is used to obtain the Cell Reversible Voltage $\mathbf{E}_{\text {Nernst }}$ taking into account changes in temperature with respect to the standard reference temperature $[7,8]$. Then all the voltage losses are considered using the following equations:

\section{Activation Losses:}

The activation voltage drop, including both anode and cathode, can be calculated using [5, 7]:

$\Delta \mathrm{V}_{\mathrm{act}}=-\left[\xi_{1}+\xi_{2}^{*} \mathrm{~T}+\xi_{3}{ }^{*} \mathrm{~T} * \ln \left(\mathrm{C}_{\mathrm{O} 2}\right)+\xi_{4}{ }^{*} \mathrm{~T} * \ln \left(\mathrm{i}_{\mathrm{FC}}\right)\right]$

Where: $i_{F C}$ : is the cell operating current in $(A)$.

$\mathrm{T}$ : cell operating temperature in Kelvin $(\mathrm{K})$.

$\xi$ : parametric coefficients for each cell, whose values are defined based on theoretical equations with kinetic, thermodynamic, and electrochemical foundations [5].

$\mathrm{C}_{\mathrm{O} 2}$ : is the concentration of oxygen in the catalytic interface of the cathode $\left(\mathrm{mol} / \mathrm{cm}^{3}\right)$, and determined by: $\mathrm{C}_{\mathrm{O} 2}=\mathrm{P}_{\mathrm{O} 2} /\left(5.08 * 10^{6} * \mathrm{e}^{(-498 / \mathrm{T})}\right)$

\section{Ohmic Losses:}

It will be obtained using the general expression for resistance including all membrane parameters.

$\mathrm{R}_{\mathrm{M}}=\rho_{\mathrm{M}} * \mathrm{~L} / \mathrm{A}$

Where: L: thickness of the membrane in $\mathrm{cm}$

A: cell active area in $\mathrm{cm}^{2}$.

$\rho_{M}$ is the specific resistivity of the membrane to the electron flow $(\Omega \mathrm{cm})$ given by [5]:

$\rho_{\mathrm{M}}=\left(181.6 *\left[1+0.03 *\left(\mathrm{i}_{\mathrm{FC}} / \mathrm{A}\right)+0.062 *(\mathrm{~T} / 303)^{2} *\right.\right.$ $\left.\left.\left(\mathrm{i}_{\mathrm{FC}} / \mathrm{A}\right)^{2.5}\right]\right) /\left(\left[\psi-0.634-3 *\left(\mathrm{i}_{\mathrm{FC}} / \mathrm{A}\right)\right] * \exp [4.18 *((\mathrm{~T}-\right.$ 303)/T)] )

Where, the exponential term is the temperature correction if the cell is not operating at $30^{\circ} \mathrm{C}(303 \mathrm{~K})$.

$\Psi=14$ (ideal condition), 23 (oversaturated).

Then the ohmic voltage drop is determined by:

$\Delta \mathrm{V}_{\mathrm{ohm}}=\mathrm{i}_{\mathrm{FC}}{ }^{*}\left(\mathrm{R}_{\mathrm{M}}+\mathrm{R}_{\mathrm{C}}\right)$

(16)

Where: $R_{C}$ is resistance to protons transfer through the membrane, and usually considered constant.

\section{Concentration Losses:}

This will be determined by:

\begin{tabular}{|l}
$\Delta \Delta V_{\text {con }}=-B^{*} \ln \left(1-j / j_{\text {max }}\right)$ \\
Where: $B$ : is a parametric coefficient in volts, which
\end{tabular} depends on the cell and its operation state.

$j=i_{F C} / A$ : actual current density of the cell $\left(\mathrm{A} / \mathrm{cm}^{2}\right)$.

$\mathrm{j}_{\max }$ : is the maximum current density at which the fuel is used at same rate of the maximum supply speed, it is in range of $\left(500-1500 \mathrm{~mA} / \mathrm{cm}^{2}\right)$.

The above equations were all implemented in MATLAB/Simulink [9] software to develop a prototype for simulating the fuel cell. The proposed model prototype was then validated using the same Ballard V PEMFC. Parameters used for this simulation is given in table 3 .

Table (3) Parameters of the used Ballard Mark V Fuel Cel

\begin{tabular}{|c|c|c|c|}
\hline Parameter & Value & Parameter & Value \\
\hline $\mathrm{T}$ & $\begin{array}{llll}70 & { }^{\circ} \mathrm{C} & (343 \\
\mathrm{K}) & & & \\
\end{array}$ & $\xi_{1}$ & -0.948 \\
\hline A & $50.6 \mathrm{~cm}^{2}$ & $\xi_{2}$ & $\begin{array}{l}0.00286+0.0002^{*} \\
\ln (\mathrm{A})+\left(4.3^{*} 10^{-5}\right)^{*} \\
\ln \mathrm{C}_{\mathrm{H} 2}\end{array}$ \\
\hline $\mathrm{L}$ & $178 * 10^{-4} \mathrm{~cm}$ & $\xi_{3}$ & $7.6^{*} 10^{-5}$ \\
\hline $\mathrm{P}_{\mathrm{H} 2}$ & $1 \mathrm{~atm}$. & $\xi_{4}$ & $-1.93 * 10^{4}$ \\
\hline $\mathrm{P}_{\mathrm{O} 2}$ & $1 \mathrm{~atm}$. & $\Psi$ & 23 \\
\hline $\mathrm{B}$ & $0.016 \mathrm{~V}$ & $j_{\max }$ & $1.5 \mathrm{~A} / \mathrm{cm}^{2}$ \\
\hline $\mathrm{R}_{\mathrm{C}}$ & $0.0003 \Omega$ & $j_{n}$ & $0.0012 \mathrm{~A} / \mathrm{cm}^{2}$ \\
\hline
\end{tabular}

Results of the proposed model given by figure 4 , when compared to fig. 3 , confirm that the proposed model prototype is more accurate than the simplified one in simulating the fuel cell at higher current densities above $1 \mathrm{~A} / \mathrm{cm}^{2}$.

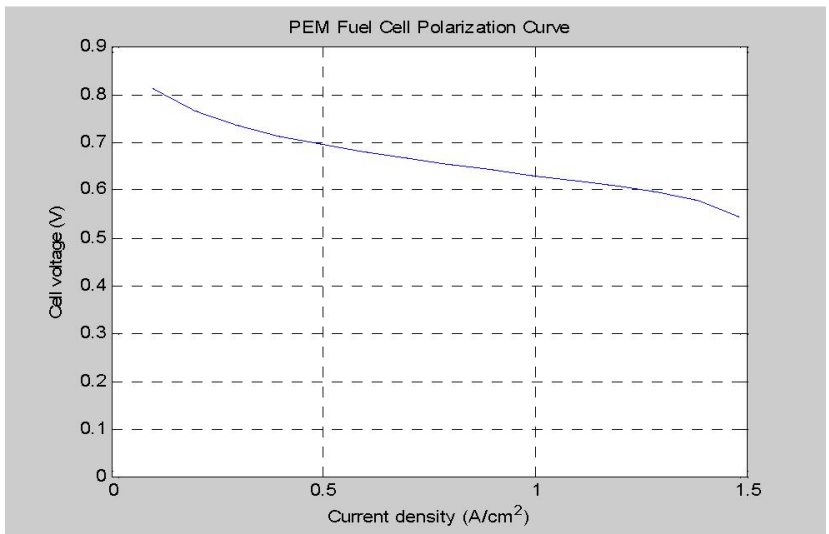

Fig. 4: Resulting Polarization Curve for a fuel cell operating at atmospheric pressure using the proposed fuel cell model (current density up to $1500 \mathrm{~mA} / \mathrm{cm}^{2}$ or $1.5 \mathrm{~A} / \mathrm{cm}^{2}$ )

The effect of fuel input pressure was also included in the proposed model prototype. An increased fuel input pressure by $0.5 \mathrm{~atm}$ was found to raise the exchange current density, which has an apparent effect of raising the open circuit voltage from 0.8 to $0.9 \mathrm{~V}$ as can be seen in fig. 5 compared to fig. 4

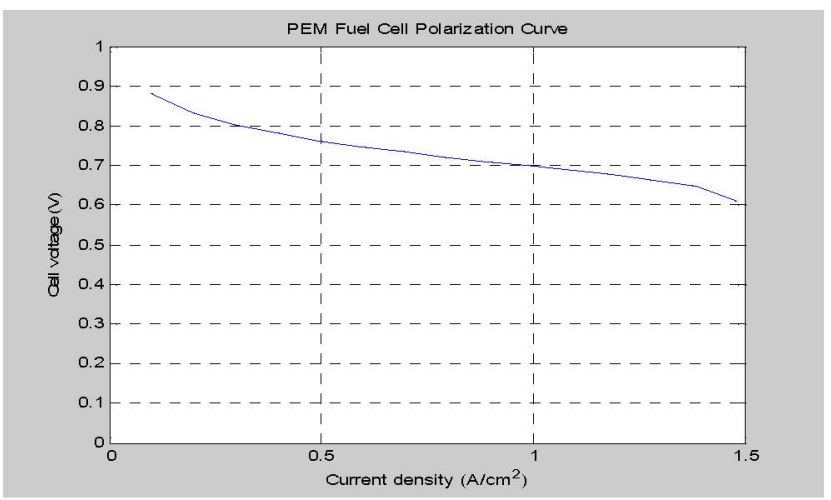

Fig. 5: Polarization Curve using shows the resulting boost in fuel cell voltage when operating at a higher hydrogen pressure.

The total number of cells in a stack affects the resulting voltage as can be seen in Fig. 6, using 1000 cells raised the stack voltage to $800 \mathrm{~V}$ at normal operating pressure.

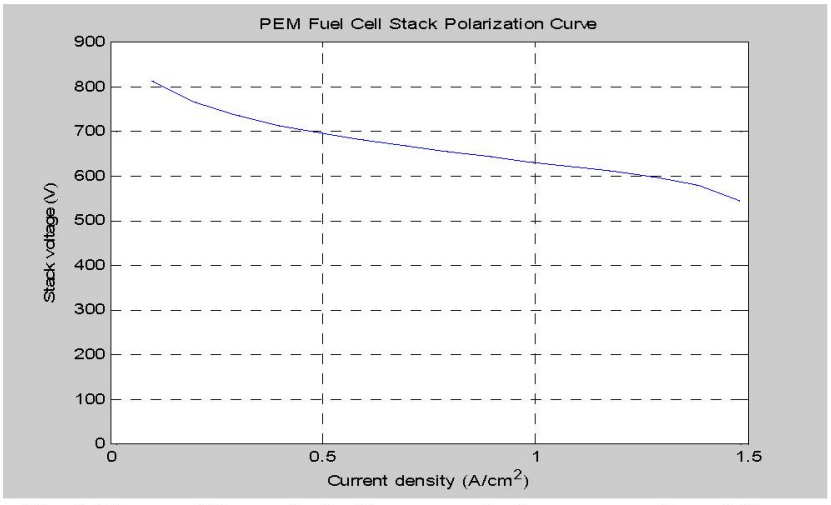

Fig. 6 The resulting polarization curve (using proposed model) for a stack PEMFC system made of 1000 cells 


\section{STACK EFFICIENCY}

Efficiency $\eta=$ electrical energy produced per mole of fuel/- $\Delta \mathrm{h}_{\mathrm{f}}$

Where: $\Delta \mathrm{h}_{\mathrm{f}},=-241.83 \mathrm{~kJ} / \mathrm{mol}$ if product is steam and is $285.84 \mathrm{~kJ} / \mathrm{mol}$ if product water. The maximum possible efficiency (thermodynamic efficiency) is when the electrical energy is equal to change in Gibbs free energy.

$\therefore$ Maximum efficiency possible $=\Delta \mathrm{g}_{\mathrm{f}} / \Delta \mathrm{h}_{\mathrm{f}} \times 100 \%$

The output voltage of a fuel cell $\mathbf{V}_{\mathbf{c}}$ is then related to efficiency by adapting equation (2). If all the energy from the hydrogen fuel is transformed to electrical energy, then: $\mathrm{E}=-\Delta \mathrm{h}_{\mathrm{f}} / 2 \mathrm{~F}=(1.48)$ at $\mathrm{HHV}$ and $(1.25)$ at LHV

Therefore actual efficiency (output/input) is then:

$\eta=\left(V_{c} / 1.48\right) \times 100 \% \quad$ (with reference to HHV)

$\eta=\left(V_{c} / 1.25\right) \times 100 \% \quad$ (with reference to LHV)

However, in practice not all the fed fuel is used. Thus a fuel utilization coefficient can be defined as:

$\mu_{\mathrm{f}}=\frac{\text { mass of cell's reacted fuel }}{\text { mass of input fuel to cell }}$

$\eta=\mu_{\mathrm{f}} \mathrm{V}_{\mathrm{c}} / 1.48100 \%$ (with reference to HHV)

$\eta=\mu_{\mathrm{f}} \mathrm{V}_{\mathrm{c}} / 1.25100 \% \quad$ (with reference to LHV)

This equation (HHV) is implemented in both the simplified and proposed models' prototypes to obtain the efficiency curves. Results for the used Ballard V PEMFC were found and compared for both models, figures $7 \& 8$.

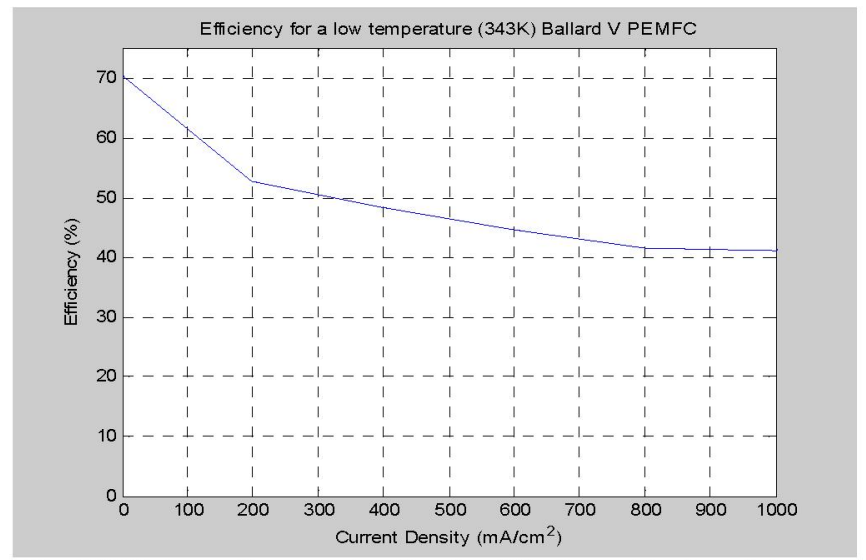

Fig. 7 Efficiency Curve using the simplified empirical model prototype (reference to $\mathrm{HHV}$, current density can't exceed $1000 \mathrm{~mA} / \mathrm{cm}^{2}$ )

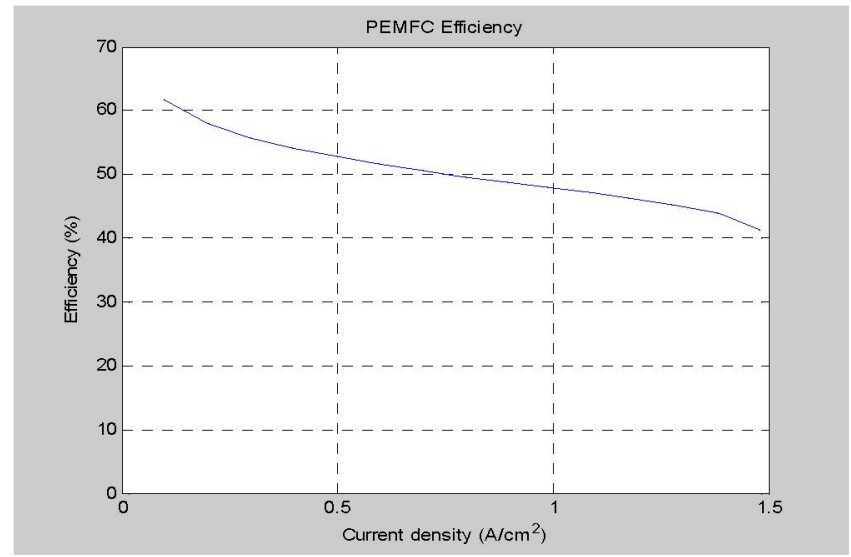

Fig.8 Efficiency Curve using the proposed model prototy pe (reference to $\mathrm{HHV}$, current density up exceeds $1000 \mathrm{~mA} / \mathrm{cm}^{2}$ )

\section{CONCLUSION}

Two prototypes for modelling the fuel cell, by using both the simplified [2] and the proposed mathematical models respectively, were developed tested and compared. Although the prototype produced using the simplified model gave reasonable results, the proposed model prototype was found to give better results especially at current densities greater than $1 \mathrm{~A} / \mathrm{cm}^{2}$. A further advantage of the proposed prototype is that it can be changed easily because it is built out of different autonomous operating blocks. The proposed prototype can be useful in many applications in future such as:

1. Estimate the performance of a specific fuel cell system and investigate its behaviour as an initial step toward investigating internal design modifications and/or external controller designs to improve its transient response.

2. Estimate the performance of a specific application that uses a fuel cell system, for example the integration of a fuel cell into a power system.

\section{REFERENCES}

1. Kyoungsoo Ro and Saifur Rahman, "Two loop Controller for Maximizing Performance of a Grid Connected Photovoltaic-Fuel Cell Hybrid Power Plant," IEEE Transaction on Energy Conversion, Vol. 13, No. 3, September 1998.

2. J. H. Lee, T. R. Lalk, "Modelling Fuel Cell Stack Systems," Journal of Power Sources 73 (1998), pp $229-241$.

3. M. D. Lucas, K. Y. Lee and H. G. Ayagh, "Development of a stack Simulation Model for Control Study on Direct Reforming Molten Carbonate Fuel Cell Power Plant," IEEE Transactions on Energy Conversion, Vol.14, No.4, December 1999.

4. R. F. Mann, J. C. Amphlett, M.A. I. Hooper, H. M. Jensen, B. A. Peppley, and P. R. Roberge, "Development and Application of a generalized steady-state electrochemical model for a PEM fuel cell," J. Power Sources, vol.86, 2000, pp. 173-180.

5. Lu-Ying Chiu, Bill Diong, and Randall S. Gemmen, "An Improved Small-Signal Model of Dynamic Behaviour of PEM Fuel Cells," IEEE Transactions on Industry Applications, Vol.40, July/August 2004.

6. Jeferson M. Correa, Felix A. Farret, Luciane N. Canha and Marcelo G. Simoes, "Electrochemical Based Fuel Cell Model suitable for Electrical Engineering Automation Approach," IEEE 2004.

7. James Larminie and Andrew Dicks, "Fuel Cell Systems Explained, Second Edition," John Willey \& Sons Ltd 2003.

8. Jay T, Pukrushpan, Anna G Stefanopoulo and Huei Peng, "Control of Fuel Cell Power Systems: Principles, modelling, analysis \& feedback design," Springer 2004

9. William J. Palm, "Introduction to Mat lab 7 for Engineers," McGraw Hill. 